\title{
Streptomyces hainanensis sp. nov., a novel member of the genus Streptomyces
}

\author{
Yi Jiang, ${ }^{1,2}$ Shu-Kun Tang, ${ }^{2}$ Jutta Wiese, ${ }^{1}$ Li-Hua $X{ }^{2}{ }^{2}$ \\ Johannes F. Imhoff ${ }^{1}$ and Cheng-Lin Jiang ${ }^{2}$ \\ ${ }^{1}$ Leibniz-Institut für Meereswissenschaften, IFM-GEOMAR, Düsternbrooker Weg 20, \\ D-24105 Kiel, Germany \\ ${ }^{2}$ Yunnan Institute of Microbiology, Yunnan University, Kunming 650091, People's Republic of China
}

Correspondence

Johannes F. Imhoff

jimhoff@ifm-geomar.de

Li-Hua Xu

lihxu@ynu.edu.cn

\begin{abstract}
A novel isolate belonging to the genus Streptomyces, strain YIM $47672^{\top}$, was obtained from soil from Hainan, an island in China. The characterization of this isolate was performed by using a polyphasic approach. The strain formed long spore chains in the aerial mycelia. The cell wall contained L-diaminopimelic acid, traces of meso-diaminopimelic acid and glycine. Whole-cell hydrolysates contained galactose and xylose. The phospholipid was of type II. The 16S rRNA gene sequence similarities for YIM $47672^{\top}$ with respect to the most closely related type strains of species of the genus Streptomyces were less than $96.3 \%$. Therefore strain YIM $47672^{\top}$ represents a novel member of the genus Streptomyces, for which the name Streptomyces hainanensis sp. nov. is proposed. The type strain is YIM $47672^{\top}$ (=CCTCC AA $205017^{\top}=$ DSM $\left.41900^{\top}\right)$.
\end{abstract}

The genus Streptomyces was proposed by Waksman \& Henrici (1943) and emended by Rainey et al. in Stackebrandt et al., 1997). Kim et al. (2003) proposed the emendation of the description of the family Streptomycetaceae, which comprises the genera Streptomyces, Kitasatospora (Zhang et al., 1997) and Streptacidiphilus (Kim et al., 2003). Members of the family Streptomycetaceae have attracted great attention because of their production of various natural products of considerable commercial value (Berdy, 2005).

In the course of our research on new sources of actinomycetes, we obtained morphological, physiological, chemical and phylogenetic data for isolate YIM $47672^{\mathrm{T}}$. Strain YIM $47672^{\mathrm{T}}$ was shown to represent a novel species of the genus Streptomyces.

Strain YIM $47672^{\mathrm{T}}$ was isolated, using the dilution plating method, from a soil sample collected in a forest (comprising evergreen broadleaved trees) on Wuzhi Mountain in Hainan Province, China. Selective isolation was achieved using trehalose-proline agar (Jiang et al., 2006) and incubation at $28{ }^{\circ} \mathrm{C}$ for 35 days. Strain YIM $47672^{\mathrm{T}}$ was maintained on YIM 38 medium $[10 \mathrm{~g}$ malt extract, $4 \mathrm{~g}$ yeast extract, $4 \mathrm{~g}$ glucose, vitamin mixture $(0.5 \mathrm{mg}$ each of thiamine- $\mathrm{HCl}$, riboflavin, niacin, pyridoxine- $\mathrm{HCl}$, inositol, calcium pantothenate and $\mathrm{p}$-aminobenzoic acid and $0.25 \mathrm{mg}$ biotin), $20 \mathrm{~g}$ agar; $\mathrm{pH} 7.2$ ]

The GenBank/EMBL/DDBJ accession number for the 16S rRNA gene sequence of strain YIM $47672^{\top}$ is AM398645.
(Hayakawa \& Nonomura, 1987) at $4{ }^{\circ} \mathrm{C}$ and preserved in $20 \%(\mathrm{v} / \mathrm{v})$ glycerol at $-20{ }^{\circ} \mathrm{C}$. Biomass for chemical and molecular systematic studies was obtained by growing the strain in shake flasks (at 180 r.p.m.) using YIM 38 broth at $28{ }^{\circ} \mathrm{C}$ for $4-7$ days. Cultural characteristics were determined, after 2 weeks incubation at $28{ }^{\circ} \mathrm{C}$, with the methods used in the International Streptomyces Project (Shirling \& Gottlieb, 1966). Czapek's agar and nutrient agar were prepared as described by Dong \& Cai (2001). Morphological properties were examined using a light microscope (BH-2; Olympus) and a scanning electron microscope (XL30 ESEM-TMP; Philips). Colour determination was performed using colour chips from the ISCC-NBS colour charts (standard samples, no. 2106) (Kelly, 1964).

Analyses of the amino acids and sugars in whole-cell hydrolysates were performed using the procedures described by Staneck \& Roberts (1974) and analysis of the phospholipids was carried out according to Lechevalier et al. (1981). Menaquinones were determined using the procedures of Collins et al. (1977). Biomass for a quantitative fatty acid analysis was prepared by scraping cell mass from plates containing trypticase soy broth (BBL; $3 \%, \mathrm{w} / \mathrm{v}$ ) and Bacto agar (Difco; $1.5 \%, \mathrm{w} / \mathrm{v}$ ), that had been incubated for 5 days at $28{ }^{\circ} \mathrm{C}$. The fatty acids were extracted, methylated and analysed by using the standard MIDI (Microbial Identification) system (Kämpfer \& Kroppenstedt, 1996; Sasser, 1990). Chromosomal DNA of strain YIM $47672^{\mathrm{T}}$ was extracted as described by Marmur (1961). The DNA G + C content was determined by HPLC 
(Tamaoka \& Komagata, 1984) with an Agilent 1100 LC system (IRIS Technologies).

The cell wall of strain YIM $47672^{\mathrm{T}}$ contained LLdiaminopimelic acid, traces of meso-diaminopimelic acid and glycine. Whole-cell hydrolysates consisted of galactose and xylose. The analysis of the polar lipids revealed the presence of phosphatidylethanolamine and diphosphatidylglycerol, indicating that the phospholipid was of type II sensu Lechevalier et al. (1977). The major components of the fatty acid profile included iso-branched hexadecanoic acid (iso- $\left.\mathrm{C}_{16: 0}\right)$, hexadecanoic acid $\left(\mathrm{C}_{16: 0}\right)$ and anteisobranched heptadecanoic acid $\left(\mathrm{C}_{17: 0}\right)$. These characteristics are consistent with membership of the family Streptomycetaceae. According to Kim et al. (2003), the major menaquinones of the genus Streptomyces are MK-9 $\left(\mathrm{H}_{6}\right)$ and MK-9 $\left(\mathrm{H}_{8}\right)$. Strain YIM $47672^{\mathrm{T}}$ also contained MK$9\left(\mathrm{H}_{6}\right)(14.0 \%)$ and MK- $9\left(\mathrm{H}_{8}\right)(13.6 \%)$, but the predominant menaquinones were MK-9 $\left(\mathrm{H}_{4}\right)(45.4 \%)$ and MK$10\left(\mathrm{H}_{0}\right)(27.0 \%)$. The $\mathrm{G}+\mathrm{C}$ content of genomic DNA from strain YIM $47672^{\mathrm{T}}$ was $73.4 \mathrm{~mol} \%$.

Strain YIM $47672^{\mathrm{T}}$ grew well on most of the media tested (Table 1). Aerial mycelia developed well, were long and branched and ranged in colour from white to pink-white and pink-grey. Vegetative mycelia developed well, and ranged in colour from a pale to a deep orange-yellow. Light brown to yellowish orange soluble pigments were produced. Spore chains were spiral or retinaculiaperti (looped at the top) in nature (Fig. 1). Spores were elliptical or shaped like short rods $(0.4-0.6 \times 0.7-1.0 \mu \mathrm{m}$. The spore surfaces were smooth.

A range of phenotypic properties was examined using standard procedures (Goodfellow, 1971; Williams et al. 1983). In addition, acid production from carbohydrates was tested using the media and methods described by Gordon et al. (1974). The utilization of carbon and nitrogen sources was determined by using the methods of Gordon \& Mihm (1962) and Tsukamura (1966). Strain YIM $47672^{\mathrm{T}}$ was negative in tests for gelatin liquefaction, milk coagulation and peptonization, arginase activity, phenylalanine deaminase activity, DNase activity and melanin production. The strain was positive in tests for

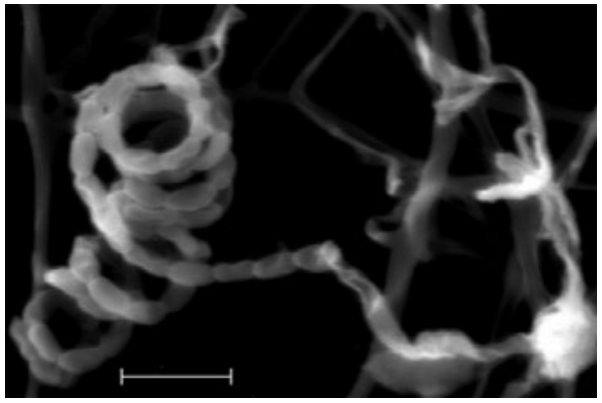

Fig. 1. Scanning electron micrograph of spiral spore chains of strain YIM $47672^{\top}$ after growth on YIM 38 medium for 14 days. Bar, $2 \mu \mathrm{m}$.

starch hydrolysis, arginine decarboxylase activity, nitrate reduction, gas production from nitrate, growth on cellulose and $\mathrm{H}_{2} \mathrm{~S}$ production. Growth occurred at $\mathrm{pH}$ 6.0-9.0 (optimum, pH 7.0) and with $0-10 \% \mathrm{NaCl}$ (optimum, $0 \%$ $\mathrm{NaCl})$. Glucose, cellobiose, starch, aesculin, trehalose, $\beta$ galactoside and urea were utilized; acids were not produced from these carbon sources. A broad range of additional carbon sources, as well as three nitrogen sources, were tested and shown not to be utilized.

The almost-complete 16S rRNA gene sequence of strain YIM $47672^{\mathrm{T}}$ was aligned with sequences of related type strains, as well as with sequences of representative Streptomyces species (obtained from the GenBank/EMBL/ DDBJ and RDPII databases). The CLUSTAL_X program (Thompson et al., 1997) was used for multiple alignments (corrected manually). In addition, a second alignment method, ARB, was used. Both alignment methods revealed the same tree topology (data not shown). The phylogenetic analysis was performed with the ARB alignment and the neighbour-joining method (Saitou \& Nei, 1987) using the Kimura two-parameter model (Kimura, 1980) using the MEGA3.1 software package (Kumar et al., 2004). The PHYML software package (Guindon et al., 2005) was used to construct the maximum-likelihood tree, using the general time reversible (GTR) model. The topologies of the trees

Table 1. Cultural characteristics of strain YIM $47672^{\top}$

+ , Poor; ++ , moderate; +++ , good; - , not present.

\begin{tabular}{|c|c|c|c|c|c|c|}
\hline \multirow[t]{2}{*}{ Media } & \multirow[t]{2}{*}{ Growth } & \multicolumn{2}{|c|}{ Aerial mycelium } & \multicolumn{2}{|c|}{ Substrate mycelium } & \multirow[t]{2}{*}{ Soluble pigment } \\
\hline & & Presence & Colour & Presence & Colour & \\
\hline Glycerol-asparagine agar (ISP 5) & + & - & None & + & Pale yellow & None \\
\hline Inorganic salts-starch agar (ISP 4) & ++ & ++ & Pink-white & ++ & Light reddish brown & Pale orange-yellow \\
\hline Yeast extract-malt extract agar (ISP 2) & ++ & ++ & Pink-white & ++ & Brilliant orange-yellow & Orange-yellow \\
\hline
\end{tabular}


were evaluated by using bootstrap analysis (Felsenstein, 1985) based on 1000 resamplings (neighbour-joining) and 500 resamplings (maximum-likelihood), respectively. NJPLOT software (Perrière \& Gouy, 1996) was used to display the phylogenetic trees.

The phylogenetic analysis demonstrated that strain YIM $47672^{\mathrm{T}}$ belongs to the genus Streptomyces. The rooted phylogenetic tree for YIM $47672^{\mathrm{T}}$ and related and representative type strains of the genus Streptomyces indicated that this strain formed a distinct clade with an undescribed isolate, Streptomyces sp. D44 (Q. Gu, Y. Huang \& Z. Liu, unpublished; GenBank/EMBL/DDBJ accession no. DQ460471), derived from a traditional Chinese medicinal plant. Streptomyces sp. D44 was found to be the organism most closely related to strain YIM $47672^{\mathrm{T}}$ (showing $99.9 \%$ gene sequence similarity). The separate branching of this clade was supported by the neighbourjoining tree (Fig. 2) and by the maximum-likelihood tree (data not shown). An analysis of the $\gamma$-region sequences of

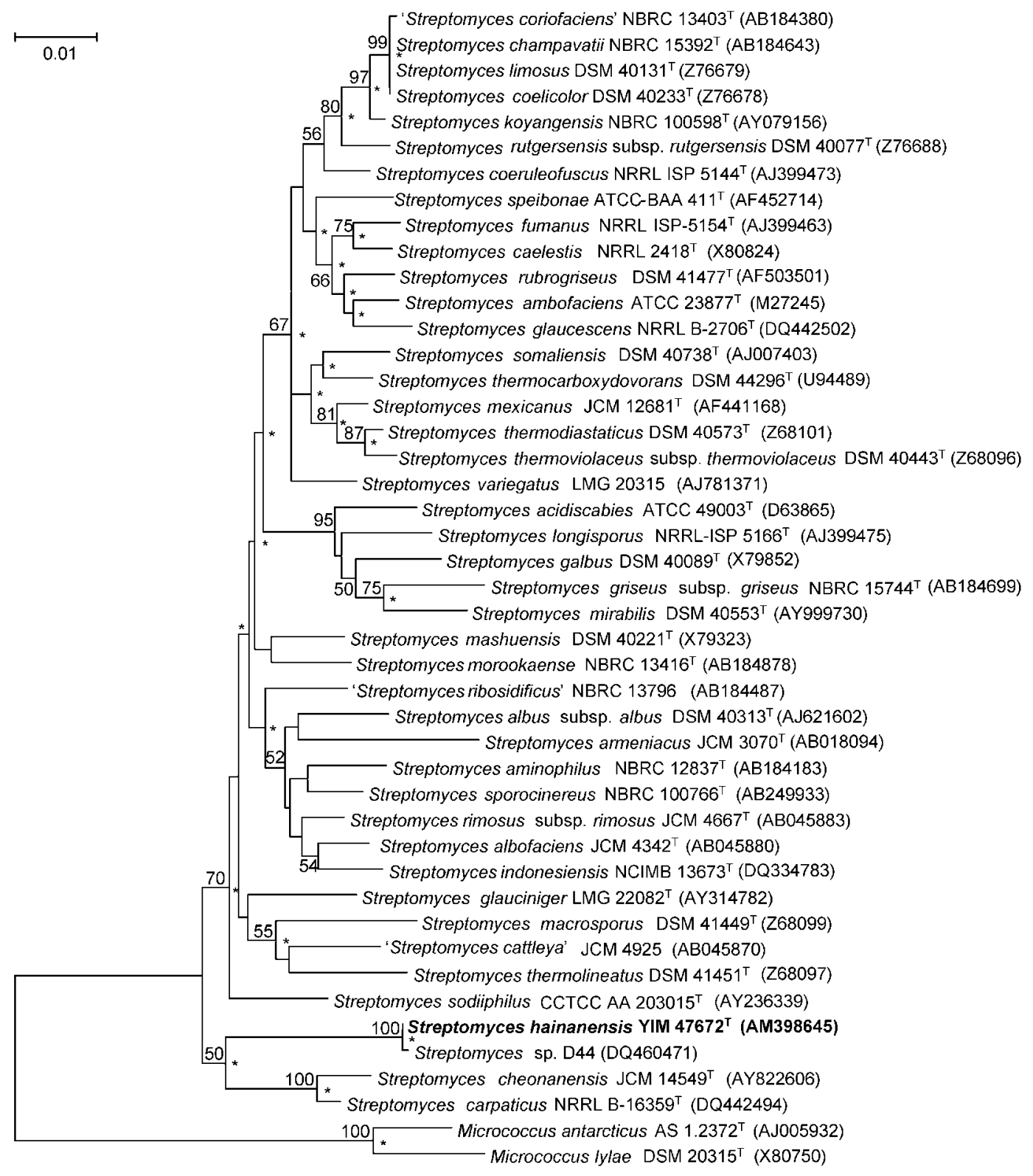

Fig. 2. Neighbour-joining phylogenetic tree, based on $16 \mathrm{~S}$ rRNA gene sequences (1412 bp, by omitting unaligned regions), showing the relationships between strain YIM $47672^{\top}$ and related and representative species of the genus Streptomyces. Type strains of the genus Micrococcus were used as an outgroup. Numbers at branching points indicate bootstrap percentages (based on 1000 replications). Asterisks indicate branches that were also obtained using maximum-likelihood analysis. Bar, 0.01 substitutions per nucleotide position. 
the 43 Streptomyces strains shown in the phylogenetic trees (positions 158-277 on the 16S rRNA gene; Kataoka et al., 1997) confirmed the affiliation of strain YIM $47672^{\mathrm{T}}$ to a separate branch (data not shown). Streptomyces sodiiphilus CCTCC AA $203015^{\mathrm{T}}$ clustered with Streptomyces rimosus subsp. rimosus JCM $4667^{\mathrm{T}}$, Streptomyces albus subsp. albus DSM $40313^{\mathrm{T}}$ and Streptomyces albofaciens JCM $4342^{\mathrm{T}}$. Streptomyces cheonanensis JCM $14549^{\mathrm{T}}$ belonged to a cluster consisting of Streptomyces carpaticus NRRL B$16359^{\mathrm{T}}$, Streptomyces armeniacus JCM $3070^{\mathrm{T}}$, the suggested type strain of 'Streptomyces cattleya' JCM 4925, Streptomyces macrosporus DSM $41449^{\mathrm{T}}$ and Streptomyces thermolineatus DSM $41451^{\mathrm{T}}$.

The 16S rRNA gene sequence similarities between strain YIM $47672^{\mathrm{T}}$ and the type strains of closely related Streptomyces species with validly published names were 96.2\% (for S. sodiiphilus; Li et al., 2005), $95.95 \%$ (for S. carpaticus; Gause et al., 1983, 1986) and $95.81 \%$ (for $S$. cheonanensis; Kim et al., 2006). The levels of gene sequence similarity with respect to other members of the genus Streptomyces ranged from 93.40 to $95.50 \%$.

Strain YIM $47672^{\mathrm{T}}$ showed some characteristics that differed from those of its closest relatives. Whole-cell hydrolysates of $S$. sodiiphilus contain mainly galactose and glucose, the predominant menaquinones are MK-9 $\left(\mathrm{H}_{4}\right)$ $(13 \%)$, MK-9 $\left(\mathrm{H}_{6}\right)(68 \%)$ and MK- $9\left(\mathrm{H}_{8}\right)(19 \%)$ and the $\mathrm{G}+\mathrm{C}$ content is $70.5 \mathrm{~mol} \%$. S. cheonanensis shows rectiflexibiles spore chains, the aerial mycelium is grey and the substrate mycelium is light yellow; it produces brown and dark grey soluble pigments, produces melanin, utilizes arabinose, mannitol, raffinose and xylose and the DNA G + C content is $75.5 \mathrm{~mol} \%$. The description of $S$. carpaticus focused mainly on its morphological and physiological characteristics (Spirales spore chains dark brown mycelium on ISP 4 agar, utilization of rhamnose, arabinose, mannitol, raffinose, fructose and xylose).

It can be concluded, therefore, that strain YIM $47672^{\mathrm{T}}$ represents a novel member of the genus Streptomyces, for which the name Streptomyces hainanensis sp. nov. is proposed.

\section{Description of Streptomyces hainanensis sp. nov.}

Streptomyces hainanensis (hai.nan.en'sis. N.L. adj. hainanensis pertaining to Hainan, a province of south China, from where the type strain was isolated).

Aerial mycelia are white and pink-white to pink-grey. Spore chains are spiral or looped. Spores are elliptical or shaped like short rods. Spore surface is smooth. Vegetative mycelia are pale to deep orange-yellow. Produces light brown to orange-yellowish soluble pigments. Negative in tests for gelatin liquefaction, milk coagulation and peptonization, arginase activity, phenylalanine deaminase activity, DNase and melanin production. Positive for starch hydrolysis, arginine decarboxylase activity, nitrate reduction, gas production from nitrate, growth on cellulose and
$\mathrm{H}_{2} \mathrm{~S}$ production. Optimal growth occurs at $\mathrm{pH} 7.0$ (range, $\mathrm{pH}$ 6.0-9.0) and without $\mathrm{NaCl}$ (range, $0-10 \% \mathrm{NaCl}$ ). Glucose, cellobiose, starch, aesculin, trehalose, $\beta$-galactoside and urea are utilized; acids are not produced from these carbon sources. Galactose, mannose, fructose, arabinose, xylose, ribose, rhamnose, sucrose, lactose, maltose, melibiose, raffinose, turanose, melezitose, sorbin, dextrin, salicin, adonitol, inositol, mannitol, sorbitol, xylitol, galactitol, erythritol, amygdaloside, sodium citrate, sodium acetate, gluconate, malonate, tartrate, lysine, ornithine and acetamide are not utilized. Resistant to the following antibiotics ( $\mu \mathrm{g}$, unless indicated otherwise): penicillin G (10 U), amoxycillin/clavulanic acid $(20: 10)$, novobiocin (30), rifampicin (5) and ampicillin (10). Sensitive to the following antibiotics $(\mu \mathrm{g}$, unless indicated otherwise): erythromycin (15), gentamicin (10), kanamycin (30), tetracycline (30), vancomycin (30), midecamycin (15), clindamycin (2), sulfamethoxazole/trimethoprim (23.75:1.25), chloramphenicol (30), polymyxin B (300 U) and norfloxacin (10). Cell wall contains Ldiaminopimelic acid, traces of meso-diaminopimelic acid and glycine. Whole-cell hydrolysates contain galactose and xylose. The diagnostic phospholipid is phosphatidylethanolamine. The predominant menaquinones are MK-9 $\left(\mathrm{H}_{4}\right)$ (45.4\%), MK-9 $\left(\mathrm{H}_{6}\right)$ (14.0\%), MK-9 $\left(\mathrm{H}_{8}\right) \quad(13.6 \%)$ and MK-10 $\left(\mathrm{H}_{0}\right) \quad(27.0 \%)$. Fatty acids comprise iso- $\mathrm{C}_{15: 0}$ $(1.1 \%)$, iso- $\mathrm{C}_{16: 0}(30.9 \%), \mathrm{C}_{16: 1} \omega 7 c / \mathrm{C}_{16: 1} \omega 6 c(2.1 \%)$, $\mathrm{C}_{16: 0}(13.7 \%)$, iso- $\mathrm{C}_{17: 1} \omega 9 c(1.4 \%)$, iso- $\mathrm{C}_{17: 0}(2.8 \%)$, anteiso- $\mathrm{C}_{17: 0}(10.8 \%), \mathrm{C}_{17: 1} \omega 8 \mathrm{c}(7.1 \%), \mathrm{C}_{17: 0}$ cyclo (1.4\%), $\mathrm{C}_{17: 0}(5.6 \%)$, anteiso- $\mathrm{C}_{18: 0} / \mathrm{C}_{18: 2} \omega 6,9 c$ (9.7\%), $\mathrm{C}_{18: 1} \omega 9 c(4.9 \%)$ and $\mathrm{C}_{18: 0}(1.2 \%)$. In addition, the sum of $\mathrm{C}_{16: 1} \omega 7 c / \mathrm{C}_{16: 1} \omega 6 c$ was $2.1 \%$, the sum of anteiso- $\mathrm{C}_{18: 0} /$ $\mathrm{C}_{18: 2} \omega 6,9 c$ was $9.7 \%$ and the sum of iso- $\mathrm{C}_{17: 1} \omega 9 c$ and/or $\mathrm{C}_{16: 0}$ 10-methyl was $1.4 \%$. The $\mathrm{G}+\mathrm{C}$ content of genomic DNA is $73.4 \mathrm{~mol} \%$.

The type strain, YIM $47672^{\mathrm{T}} \quad(=$ CCTCC AA $205017^{\mathrm{T}}=$ DSM $\left.41900^{\mathrm{T}}\right)$, was isolated from soil collected from a forest (of evergreen broadleaved trees) on Wuzhi Mountain, Hainan Province, China.

\section{Acknowledgements}

This research was supported by the National Basic Research Program of China (no. 2004CB719601), the National Natural Science Foundation of China (no. 30560001), the Yunnan Provincial International Cooperative Program (no. 2005GH21), the Yunnan Provincial Natural Science Foundation (no. 2004 C0002Q), the Program for New Century Excellent Talents in University and the Zentrum für Marine Wirkstoffe (Ministerium für Wissenschaft, Wirtschaft und Verkehr des Landes Schleswig Holstein, Germany). We thank Cai Xiang-Feng and Chen Yun for their technical assistance, Dr Vera Thiel for the ARB calculation and Dr Elena Nikulina for translation of the Russian publication.

\section{References}

Berdy, J. (2005). Bioactive microbial metabolites, a personal view. J Antibiot (Tokyo) 58, 1-26. 
Collins, M. D., Pirouz, T., Goodfellow, M. \& Minnikin, D. E. (1977). Distribution of menaquinones in actinomycetes and corynebacteria. $J$ Gen Microbiol 100, 221-230.

Dong, X. Z. \& Cai, M. Y. (2001). Manual of Systematics and Identification of General Bacteria. Beijing: Science Press.

Felsenstein, J. (1985). Confidence limits on phylogenies: an approach using the bootstrap. Evolution 39, 783-791.

Gause, G. F., Preobrazhenskaya, T. P., Sveshnikova, M. A., Terekhova, L. P. \& Maximova, T. S. (1983). A guide for the determination of actinomycetes. Genera Streptomyces, Streptoverticillium, and Chaina. Moscow: Nauka.

Gause, G. F., Preobrazhenskaya, T. P., Sveshnikova, M. A., Terekhova, L. P. \& Maximova, T. S. (1986). Streptomyces carpaticus sp. nov. In Validation of the Publication of New Names and New Combinations Previously Effectively Published Outside the IJSB, List no. 22. Int J Syst Bacteriol 36, 573-576.

Goodfellow, M. (1971). Numerical taxonomy of some nocardioform bacteria. J Gen Microbiol 69, 33-80.

Gordon, R. E. \& Mihm, J. M. (1962). The type species of the genus Nocardia. J Gen Microbiol 27, 1-10.

Gordon, R. E., Barnett, D. A., Handerhan, J. E. \& Pang, C. H.-N. (1974). Nocardia coeliaca, Nocardia autotrophica, and the nocardin strains. Int J Syst Bacteriol 24, 54-63.

Guindon, S., Lethiec, F., Duroux, P. \& Gascuel, O. (2005). PHYML Online-a web server for fast maximum likelihood-based phylogenetic inference (Web Server issue). Nucleic Acids Res 33, W557-W559.

Hayakawa, M. \& Nonomura, H. (1987). Humic acid-vitamin agar, a new medium for selective isolation of soil actinomycetes. J Ferment Technol 65, 501-509.

Jiang, Y., Duan, S. R., Tang, S. K., Cheng, H. H., Li, W. J. \& Xu, L. H. (2006). Isolation methods of rare actinomycetes. Microbiology [English translation of Microbiology (Beijing)] 33, 181-183.

Kämpfer, P. \& Kroppenstedt, R. M. (1996). Numerical analysis of fatty acid patterns of coryneform bacteria and related taxa. Can J Microbiol 42, 989-1005.

Kataoka, M., Ueda, K., Kudo, T., Seki, T. \& Yoshida, T. (1997). Application of the variable region in $16 \mathrm{~S}$ rDNA to create an index for rapid species identification in the genus Streptomyces. FEMS Microbiol Lett 151, 249-255.

Kelly, K. L. (1964). Inter-Society Color Council - National Bureau of Standards Color Name Charts Illustrated with Centroid Colors. Washington, DC: US Government Printing Office.

Kim, S. B., Lonsdale, J., Seong, C. N. \& Goodfellow, M. (2003). Streptacidiphilus gen. nov., acidophilic actinomycetes with wall chemotype I and emendation of the family Streptomycetaceae (Waksman and Henrici $(1943)^{\mathrm{AL}}$ ) emend. Rainey et al. 1997. Antonie van Leeuwenhoek 83, 107-116.

Kim, H. J., Lee, S. C. \& Hwang, B. K. (2006). Streptomyces cheonanensis sp. nov., a novel streptomycete with antifungal activity. Int J Syst Evol Microbiol 56, 471-475.
Kimura, M. (1980). A simple method for estimating evolutionary rates of base substitutions through comparative studies of nucleotide sequences. J Mol Evol 16, 111-120.

Kumar, S., Tamura, K. \& Nei, M. (2004). MEGA3: integrated software for molecular evolutionary genetics analysis and sequence alignment. Brief Bioinform 5, 150-163.

Lechevalier, M. P., De Bièvre, C. \& Lechevalier, H. A. (1977). Chemotaxonomy of aerobic actinomycetes: phospholipid composition. Biochem Syst Ecol 5, 249-260.

Lechevalier, M. P., Stern, A. E. \& Lechevalier, H. A. (1981). Phospholipids in the taxonomy of actinomycetes. In Actinomycetes, pp. 11-116. Edited by K. P. Schaal \& G. Pulverer. New York: Gustav Fischer.

Li, W. J., Zhang, Y. Q., Tang, S. K., Xu, P., Xu, L. H. \& Jiang, C. L. (2005). Streptomyces sodiiphilus sp. nov., a novel alkaliphilic actinomycete. Int J Syst Evol Microbiol 55, 1329-1333.

Marmur, J. (1961). A procedure for the isolation of deoxyribonucleic acid from microorganisms. J Mol Biol 3, 208-218.

Perrière, G. \& Gouy, M. (1996). WWW-query: an on-line retrieval system for biological sequence banks. Biochimie 78, 364-369.

Saitou, N. \& Nei, M. (1987). The neighbor-joining method: a new method for reconstructing phylogenetic trees. Mol Biol Evol 4, 406-425.

Sasser, M. (1990). Identification of bacteria by gas chromatography of cellular fatty acids. USFCC Newsl 20, 16.

Shirling, E. B. \& Gottlieb, D. (1966). Methods for characterization of Streptomyces species. Int J Syst Bacteriol 16, 313-340.

Stackebrandt, E., Rainey, F. A. \& Ward-Rainey, N. L. (1997). Proposal for a new hierarchic classification system, Actinobacteria classis nov. Int J Syst Bacteriol 47, 479-491.

Staneck, J. L. \& Roberts, G. D. (1974). Simplified approach to identification of aerobic actinomycetes by thin layer chromatography. Appl Microbiol 28, 226-231.

Tamaoka, J. \& Komagata, K. (1984). Determination of DNA base composition by reversed-phase high-performance liquid chromatography. FEMS Microbiol Lett 25, 125-128.

Thompson, J. D., Gibson, T. J., Plewniak, F., Jeanmougin, F. \& Higgins, D. G. (1997). The CLUSTAL_X windows interface: flexible strategies for multiple sequence alignment aided by quality analysis tools. Nucleic Acids Res 25, 4876-4882.

Tsukamura, M. (1966). Adansonian classification of mycobacteria. J Gen Microbiol 45, 253-273.

Waksman, S. A. \& Henrici, A. T. (1943). The nomenclature and classification of the actinomycetes. J Bacteriol 46, 337-341.

Williams, S. T., Goodfellow, M., Alderson, G., Wellington, E. M. H., Sneath, P. H. A. \& Sackin, M. J. (1983). Numerical classification of Streptomyces and related genera. J Gen Microbiol 129, 1743-1813.

Zhang, Z., Wang, Y. \& Ruan, J. (1997). A proposal to revive the genus Kitasatospora (Omura, Takahashi, Iwai, and Tanaka 1982). Int J Syst Bacteriol 47, 1048-1054. 